Potravinarstvo Slovak Journal of Food Sciences

vol. 15, 2021, p. 1005-1017

https://doi.org/10.5219/1632

Received: 21 May 2021. Accepted: 30 September 2021. Available online: 28 October 2021 at www.potravinarstvo.com

(C) 2021 Potravinarstvo Slovak Journal of Food Sciences, License: CC BY 4.0

ISSN 1337-0960 (online)

\title{
DEVELOPMENT OF A TWO-LEVEL CONTROL SYSTEM FOR THE ANALYSIS OF THE COMPOSITION OF MEAT PRODUCTS
}

\author{
Natalya Vostrikova, Daniil Khvostov, Anatoly Zherdev, Mikhail Minaev, Elena Zvereva
}

\begin{abstract}
Because of the increased demand for processed meat, there is an urgent need to introduce specific identification methods. Strategies such as molecular genetics and the physical condition of meat are used to quickly explore multi-component products. However, a single methodology does not always unambiguously classify a product as counterfeit. In laboratory practice, as a rule, screening techniques are rarely used in the first stage, followed by arbitration. This work aimed to study individual methodologies using artificially falsified meat samples as examples and to identify their composition based on muscle tissue. For the experiments, the three most common types of raw meat were selected: pork, beef, and chicken. The calculation of the content of muscle tissue was carried out according to the BEFFE method. The study of muscle protein was carried out by ICA, ELISA, PCR, microstructural analysis, and mass spectrometric identification. In this connection, we proposed a multilevel control system for multicomponent meat products. Both classical methodologies, such as calculation by prescription bookmarks (BEFFE) and microstructural analysis, and approaches of highly sensitive methodologies, such as identification of muscle tissue by marker peptides (LC/MS-MRM) and semi-quantitative PCR analysis, were evaluated.
\end{abstract}

Keywords: biomarker; LC-MS/MS; PCR; species specificity

\section{INTRODUCTION}

Meat is a highly nutritious food that most consumers love. The variety and quality of meat, as well as its delicacy, depending on the type of meat. According to national and international regulations, all ingredients must be marked (on the label) and be traceable within the enterprise to protect the information integrity of food products. Counterfeiting, unregistered ingredients, and contamination of any food product, whether intentionally or by gross negligence, may violate both international rules and religious laws.

Counterfeiting is a crucial health and/or ethical concern, involving specific food allergies, religion, fraud, and malicious marketing practices, in addition to economic, legal, and economic concerns (Moore, Spink and Lipp, 2012; Ali et al., 2012). Over the past two decades, many researchers have sought to develop analytical methods for the species identification of meat or meat products, which were based predominantly on the assessment of either DNA or protein (Calvo, Zaragoza and Osta, 2001; He et al., 2015; Floren et al., 2015).

Molecular genetic methods of analysis, despite the significant progress in this methodology, must still be regarded as confirmatory (arbitration) methods, implemented in specialized laboratories for samples taken based on the results of the preliminary screening. Polymerase chain reaction (PCR) is a worldwide recognized arbitration method of species identification and personal identification. However, because of the high costs of the equipment and the required qualifications of the personnel, the method cannot be used in small laboratories. Therefore, the feasibility of its use in the food industry depends on a reduction in instrumental and operating costs.

Immunoassay methods allow simple and quick screening directly at the sampling site and do not require special training. Immunochromatographic analysis (ICA), based on the use of multi membrane composites - test strips on which all the immunoreagents necessary for the specific binding of the compound to be detected are initially applied - allows for rapid testing of multicomponent samples with minimal sample preparation. To obtain quantitative data, the microplate enzyme-linked immunosorbent assay (ELISA) is the optimal methodological solution.

In thermally processed foods, there may be some detection problems due to interfering compounds and the degradation of nucleic acids and proteins. Hydrolysis and denaturation are especially severe in foods that have an acidic $\mathrm{pH}$ (e.g., lemon juice or vinegar) and/or are exposed to strong heat effects (e.g., during prolonged cooking or sterilization). Thus, for the most complex food matrices, with different ingredients mixed or subjected to severe heat treatment, the need for reliable, sensitive, and selective methods continues to be high (Chernukha et al., 2019). 


\section{Scientific hypothesis}

It seemed important to develop an assessment system for controlling the composition of meat products, aimed at identifying cases of violation of established recipes using a set of methods for a two-level system of screening and arbitration control. The aim of this work was therefore to develop a two-level control system, using raw chicken products in ready-made mixtures with other types of meat as examples.

\section{MATERIAL AND METHODOLOGY \\ Samples}

The samples consisted of raw chicken (boneless breasts: $m$. pectoralis major), pork ( $m$. latissimus dorsi), and beef (thigh). Pork, beef, and chicken underwent a trimming process to separate muscle tissue from fat and connective tissue. Losses during trimming were as follows: pork $19 \%$, beef $7 \%$, and chicken $23 \%$ (including bones).

The calculation of muscle tissue content (Table 1) was carried out according to BEFFE (bindegewebseiweißfreies Fleischeiweiß, i.e., meat proteins that do not contain connective tissue) (Federal Ministry of Food and Agriculture, 2021).

The meat was minced twice in a Hurakan HKN-12SC meat grinder (China). All equipment was thoroughly rinsed after each sample. Minced meat was weighed on a balance with an error of $0.01 \mathrm{~g}$ to obtain mixtures of the prescribed formulations (Table 1). Further grinding until homogeneity was achieved was carried out on a Fimar CUCL5V240050T laboratory cutter (Italy) at a knife rotation speed of 2800 rpm for $3 \mathrm{~min}$. A homogeneous mixture of minced meat was packed in vacuum bags of $250 \pm 12 \mathrm{~g}$ each (Figure 1). Then the samples were sealed and transported on a Webomatic Easy Pack vacuum packer (Germany).
The packaged mixtures in vacuum bags were placed in a Kerres Jet-Smoke Maxi 3000 universal thermal chamber (Austria). A medium heating mode was used: $80{ }^{\circ} \mathrm{C}$, humidity $100 \%$, for $45 \mathrm{~min}$ until reaching $72{ }^{\circ} \mathrm{C}$ in the center of the piece. After reaching the desired temperature, the samples were sprayed with tap water for $30 \mathrm{~min}$ to a temperature of $35{ }^{\circ} \mathrm{C}$ (Figure 1). Then the samples were cooled to a temperature of $6 \pm 2{ }^{\circ} \mathrm{C}$.

\section{Chemicals}

All reagents used were of U.S.P. purity or higher. All solvents, including water, were used with the LC/MS label. Laboratory Methods

Immunochromatographic analysis; Linked immunosorbent assay - Homemade laboratory methods

PCR analysis - Kurbakov et al. (2019).

Microstructural analysis - Homemade laboratory methods LC-MS/MS - Khvostov, Vostrikova and Chernukha (2020).

\section{Immunochromatographic analysis}

The analysis was carried out using pre-made test strips, consisting of multi membrane composites with applied immunoreagents and components labeled with colloidal gold. Sample preparation included grinding and extraction: 15-min incubation in phosphate buffer with detergent. For thermostable biomarkers, such as troponin, a reduction in the effect of the matrix on the assay results was achieved by introducing a 3-min incubation step for the extracts in a bath of boiling water. The test strips were vertically immersed in the test sample, and after 15 min the result (staining of the test area) was checked visually or with a scanner.

Table 1 Muscle tissue content in the experimental mixtures.

\begin{tabular}{|c|c|c|c|c|c|}
\hline No & Mixture & $\begin{array}{c}\text { Processing } \\
\text { type }\end{array}$ & $\begin{array}{l}\text { Pork (90\% } \\
\text { [w/w] muscle } \\
\text { tissue), \% } \\
(w / w)\end{array}$ & $\begin{array}{c}\text { Chicken }(97 \% \\
{[w / w] \text { muscle }} \\
\text { tissue }), \%(w / w)^{1}\end{array}$ & $\begin{array}{c}\text { Beef }(97 \% \\
{[w / w] \text { muscle }} \\
\text { tissue), \% } \\
(w / w)\end{array}$ \\
\hline 1.1 & \multirow{4}{*}{ pork + chicken } & \multirow{6}{*}{$\begin{array}{l}\text { minced meat } \\
\text { mixtures }\end{array}$} & 95.00 & 5.00 & \\
\hline 1.2 & & & 90.00 & 10.00 & \\
\hline 1.3 & & & 80.00 & 20.00 & \\
\hline 1.4 & & & 60.00 & 40.00 & \\
\hline 1.5 & \multirow{2}{*}{ chicken skin + pork + chicken } & & 90.00 & $5.00+$ skin 5.00 & \\
\hline 1.6 & & & 70.00 & $17.00+$ skin 17.00 & \\
\hline $1.1 \mathrm{~b}$ & \multirow{4}{*}{ pork + chicken } & \multirow{6}{*}{$\begin{array}{c}\text { mixtures } \\
\text { cooked to a } \\
\text { core } \\
\text { temperature of } \\
72{ }^{\circ} \mathrm{C}\end{array}$} & 95.00 & 5.00 & \\
\hline $1.2 b$ & & & 90.00 & 10.00 & \\
\hline $1.3 \mathrm{~b}$ & & & 80.00 & 20.00 & \\
\hline $1.4 \mathrm{~b}$ & & & 60.00 & 40.00 & \\
\hline $1.5 b$ & \multirow{2}{*}{ chicken skin + pork + chicken } & & 90.00 & $5.00+$ skin 5.00 & \\
\hline $1.6 \mathrm{~b}$ & & & 70.00 & $17.00+$ skin 17.00 & \\
\hline 2.1 & \multirow{4}{*}{ pork + chicken + beef } & \multirow{4}{*}{$\begin{array}{l}\text { minced meat } \\
\text { mixtures }\end{array}$} & 71.25 & 5.00 & 23.75 \\
\hline 2.2 & & & 67.50 & 10.00 & 22.50 \\
\hline 2.3 & & & 60.00 & 20.00 & 20.00 \\
\hline 2.4 & & & 45.00 & 40.00 & 15.00 \\
\hline $2.1 \mathrm{~b}$ & \multirow{4}{*}{ pork + chicken + beef } & \multirow{4}{*}{$\begin{array}{l}\text { mixtures } \\
\text { cooked to a } \\
\text { core } \\
\text { temperature of } \\
72^{\circ} \mathrm{C}\end{array}$} & 71.25 & 5.00 & 23.75 \\
\hline $2.2 \mathrm{~b}$ & & & 67.50 & 10.00 & 22.50 \\
\hline $2.3 \mathrm{~b}$ & & & 60.00 & 20.00 & 20.00 \\
\hline $2.4 \mathrm{~b}$ & & & 45.00 & 40.00 & 15.00 \\
\hline
\end{tabular}




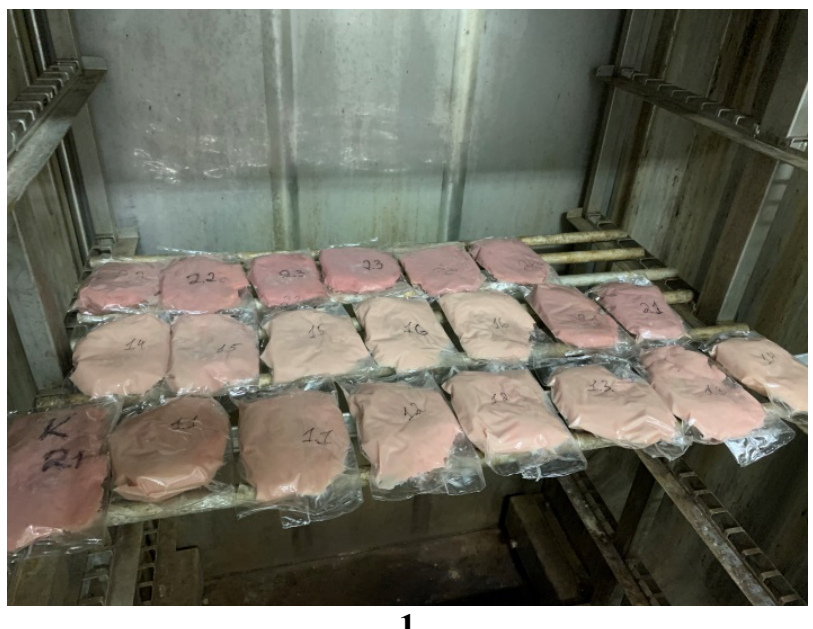

1

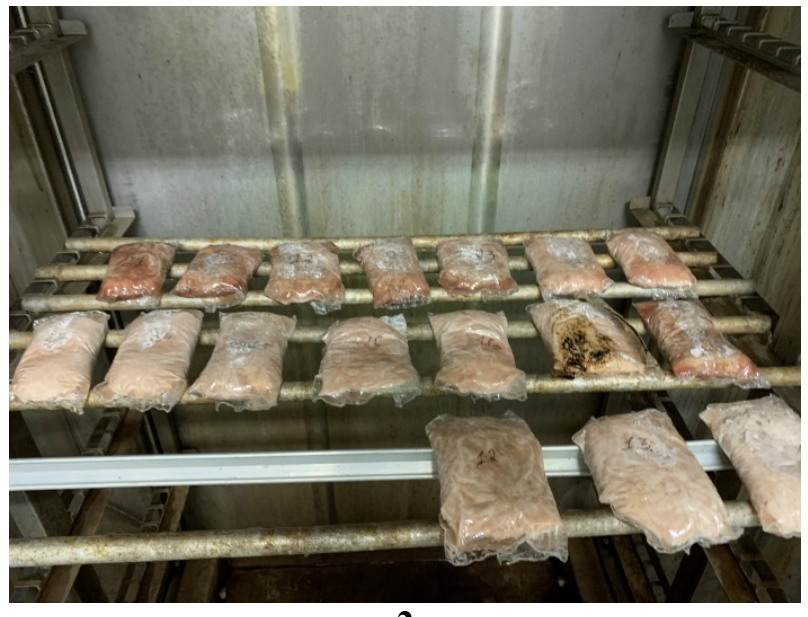

2

Figure 1 Cooking samples in a heat chamber: (1) raw and (2) after cooking.

\section{Linked immunosorbent assay}

The analysis was carried out on microplates with immobilized antibodies for the biomarker. The test sample, biotinylated specific antibodies, streptavidin-peroxidase conjugate, and peroxidase substrate mixture $\left(3,3^{\prime}, 5,5^{\prime}-\right.$ tetramethylbenzidine + hydrogen peroxide) were sequentially incubated in the microplate wells. After each stage, the plate was washed with phosphate buffer and detergent. The immune complexes formed were recorded by the optical density of the oxidized chromogenic substrate at $450 \mathrm{~nm}$.

\section{PCR analysis}

For DNA isolation, $50 \mathrm{mg}$ of food products and control samples were taken. Then lysis and purification with chloroform were carried out using the reagents of the SorbGMO-B Kit (Syntol, Moscow, Russia) according to the manufacturer's instructions. Further DNA isolation was performed at the MagNA Pure LC 2.0 isolation station (Roche) using the MagNa Pure LC DNA Isolation Kit II (Tissue) (Roche, Mannheim, Germany) (Kurbakov et al., 2019). Real-time PCR was performed on an ANK-32 amplifier (Syntol, Moscow, Russia). The reaction mixture (Syntol, Moscow, Russia), with a volume of $30 \mu \mathrm{L}$, contained primers with a concentration of $300 \mathrm{nM}$, a probe with a concentration of $150 \mathrm{nM}, 2.5 \mathrm{mM} \mathrm{MgCl}_{2}$, dNTP with a concentration of $0.25 \mathrm{mM}$ each, SynTaq polymerase with a concentration of 2.5 activity units, and $5 \mu \mathrm{L}$ of isolated DNA. The PCR reaction mode was as follows: preliminary denaturation at $95{ }^{\circ} \mathrm{C}, 7 \mathrm{~min}$, and 35 amplification cycles $\left(60^{\circ} \mathrm{C}\right.$ for $40 \mathrm{~s}$ and $95^{\circ} \mathrm{C}$ for $\left.15 \mathrm{~s}\right)$.

\section{Microstructural analysis}

In general, the preparation of histological samples included the following stages: sampling, fixation, preparation for cutting thin slices, microtomation, staining, and the interpretation of the micrographs to identify the signs of the meat product components. Properly prepared thin slices, stained to achieve the highest contrast of the analyzed components, were examined under a light microscope. First, small lens magnifications were used (10x, 20x), and then large ones (40x, 60x).

Selection of marker peptides by LC-MS/MS

Proteins were extracted from the samples and digested with trypsin based on previously published studies
(Khvostov, Vostrikova and Chernukha, 2020), and peptide mixtures were analyzed by HPLC-MS.

For chromatographic analysis, a ZORBAX Eclipse Plus C18 column with a fast HD resolution of $2.7 \mu \mathrm{m}(50 \times 2.1$ mm; Agilent Technologies, Santa Clara, California, USA) was used. Separation was performed by using an Agilent 1260 Infinity HPLC system (USA). The flow rate was set at $0.4 \mathrm{~mL} \cdot \mathrm{min}^{-1}$, the column temperature was $30^{\circ} \mathrm{C}$, and the sample temperature was $19^{\circ} \mathrm{C}$. Eluent A was water with $0.1 \%(\mathrm{v} / \mathrm{v})$ formic acid, and eluent $\mathrm{B}$ was acetonitrile with $0.1 \%(\mathrm{v} / \mathrm{v})$ formic acid. Gradient elution was performed with the following parameters: $0 \mathrm{~min} 95 \% \mathrm{~A}, 0-10 \mathrm{~min}$ from $95 \%$ A to $40 \% \mathrm{~A}, 10-15 \mathrm{~min}$ from $40 \% \mathrm{~A}$ to $0 \% \mathrm{~A}$, $15-20$ min $0 \% \mathrm{~A}, 20-21 \mathrm{~min}$ from $0 \% \mathrm{~A}$ to $95 \% \mathrm{~A}$, and 21 - $25 \mathrm{~min} 95 \%$ A (total analysis time $25 \mathrm{~min}$ ). The injection volume was $10 \mu \mathrm{L}$ for all types of samples.

Peptides were detected by using a three-quadrupole mass spectrometer (6410, Agilent Technologies, Santa Clara, California, USA) (Khvostov et al., 2019).

\section{Description of the Experiment}

Sample preparation: 20

Number of samples analyzed: 20

Number of repeated analyses: 3

Number of experiment replication: 4

\section{Statistical analysis}

STATISTICA 10.0 software (Dell Software, USA) was used for statistical analysis. Significant differences were verified by using a two-way analysis of variance (ANOVA), $p<0.05$. Differences were analyzed and reliably determined in histological and PCR studies in determining species identification for ingredients of $5 \%(\mathrm{w} / \mathrm{w})$ and above. Data were extracted from bioprograms in Microsoft Excel (USA).

\section{RESULTS AND DISCUSSION}

\section{Immunochemical methods}

The choice of a molecular identifier that is recognized by antibodies is of fundamental importance. Such a biomarker should be unique for the controlled types of raw meat products, be characterized by a stable high content of muscle tissue, and have differences in the structure of antigenic determinants in different animals. In addition, 
stability or at least preservation of the antigenic properties of the marker is required during various types of processing to which the raw meat products are subjected. To select the most promising biomarkers, we used the data of the proteomic analysis of muscle tissue proteins of different animal species and accompanying meat product components, obtained in joint studies by the Research Center of Biotechnology RAS and the V. M. Gorbatov FRC for Food Systems of the RAS (Vostrikova et al., 2017). Taking into account the above criteria, skeletal troponin I (sTnI), myoglobin, and immunoglobulins were selected as biomarkers.

\section{Immunochromatographic systems}

Based on the selected immunoreagents, an immunochromatographic test system was developed for the detection of sTnI from mammalian muscle tissues (detection limit 25 ng. $\mathrm{mL}^{-1}$ ) (Zvereva et al., 2020a). The test system allows one to quantify the content of beef in minced chicken, starting with a $1 \%$ additive. Because of the high stability of the biomarker, the system retains its effectiveness for food products subjected to heat treatment (in particular, different types of sausages). The total analysis time is $20 \mathrm{~min}$.

Table 2 The content of muscle tissue measured by PCR in the test mixtures.

\begin{tabular}{|c|c|c|c|c|c|}
\hline No & Mixture & $\begin{array}{c}\text { Processing } \\
\text { type }\end{array}$ & $\begin{array}{l}\text { Pork }(90 \% \\
\text { [w/w] muscle } \\
\text { tissue), \% } \\
(w / w)\end{array}$ & $\begin{array}{c}\text { Chicken } \\
(97 \%[w / w] \\
\text { muscle } \\
\text { tissue }), \% \\
(w / w)^{1} \\
\end{array}$ & $\begin{array}{c}\text { Beef }(97 \% \\
\text { [w/w] muscle } \\
\text { tissue), \% } \\
(w / w)\end{array}$ \\
\hline 1.1 & \multirow{4}{*}{ pork + chicken } & \multirow{6}{*}{$\begin{array}{l}\text { minced meat } \\
\text { mixtures }\end{array}$} & 94.59 & 5.41 & \\
\hline 1.2 & & & 88.31 & 11.69 & \\
\hline 1.3 & & & 80.16 & 19.84 & \\
\hline 1.4 & & & 61.88 & 38.12 & \\
\hline 1.5 & \multirow{2}{*}{ chicken skin + pork + chicken } & & 88.15 & 11.85 & \\
\hline 1.6 & & & 81.77 & 18.23 & \\
\hline $1.1 \mathrm{~b}$ & \multirow{4}{*}{ pork + chicken } & \multirow{6}{*}{$\begin{array}{c}\text { mixtures } \\
\text { cooked to a } \\
\text { core } \\
\text { temperature of } \\
72{ }^{\circ} \mathrm{C}\end{array}$} & 94.00 & 6.07 & \\
\hline $1.2 \mathrm{~b}$ & & & 90.00 & 9.84 & \\
\hline $1.3 \mathrm{~b}$ & & & 85.00 & 14.76 & \\
\hline $1.4 b$ & & & 60.50 & 39.50 & \\
\hline $1.5 b$ & \multirow{2}{*}{ chicken skin + pork + chicken } & & 89.00 & 10.77 & \\
\hline $1.6 b$ & & & 84.00 & 15.63 & \\
\hline 2.1 & \multirow{4}{*}{ pork + chicken + beef } & \multirow{4}{*}{$\begin{array}{l}\text { minced meat } \\
\text { mixtures }\end{array}$} & 78.50 & 4.53 & 16.97 \\
\hline 2.2 & & & 77.26 & 7.90 & 14.90 \\
\hline 2.3 & & & 57.31 & 21.00 & 22.00 \\
\hline 2.4 & & & 51.75 & 34.00 & 14.00 \\
\hline $2.1 \mathrm{~b}$ & \multirow{4}{*}{ pork + chicken + beef } & mixtures & 63.34 & 8.55 & 28.11 \\
\hline $2.2 \mathrm{~b}$ & & cooked to a & 65.10 & 13.60 & 21.30 \\
\hline $2.3 b$ & & core & 57.65 & 19.00 & 23.00 \\
\hline $2.4 \mathrm{~b}$ & & $\begin{array}{c}\text { temperature of } \\
72^{\circ} \mathrm{C}\end{array}$ & 52.15 & 32.85 & 15.00 \\
\hline
\end{tabular}

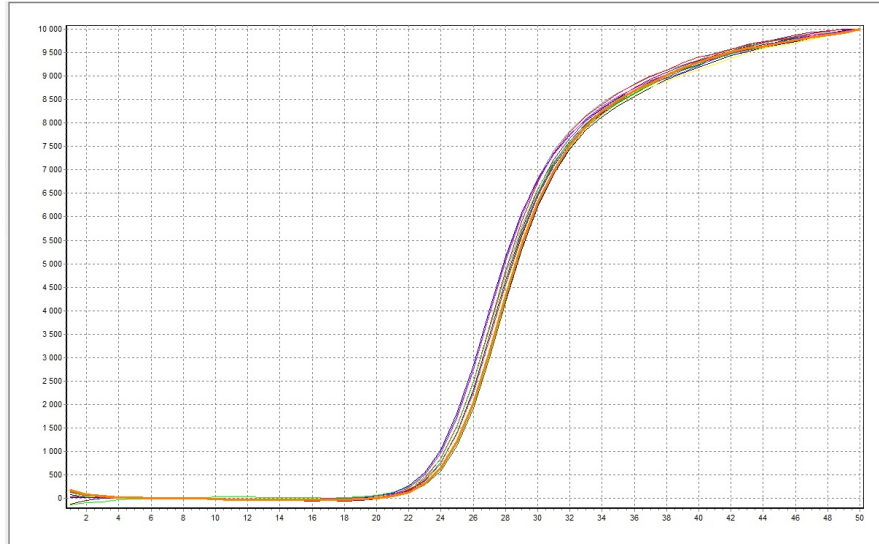

a

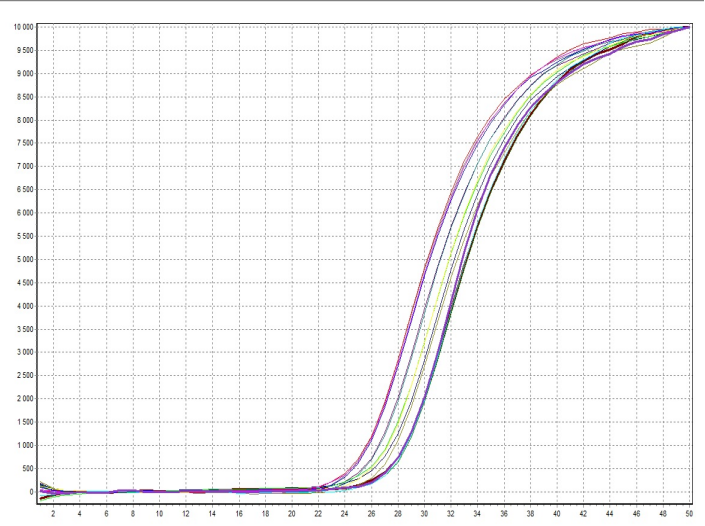

b

Figure 2 Amplification curves for Samples 1.1-1.4: (a) a reference gene common to all animal DNA and (b) a speciesspecific chicken gene. 


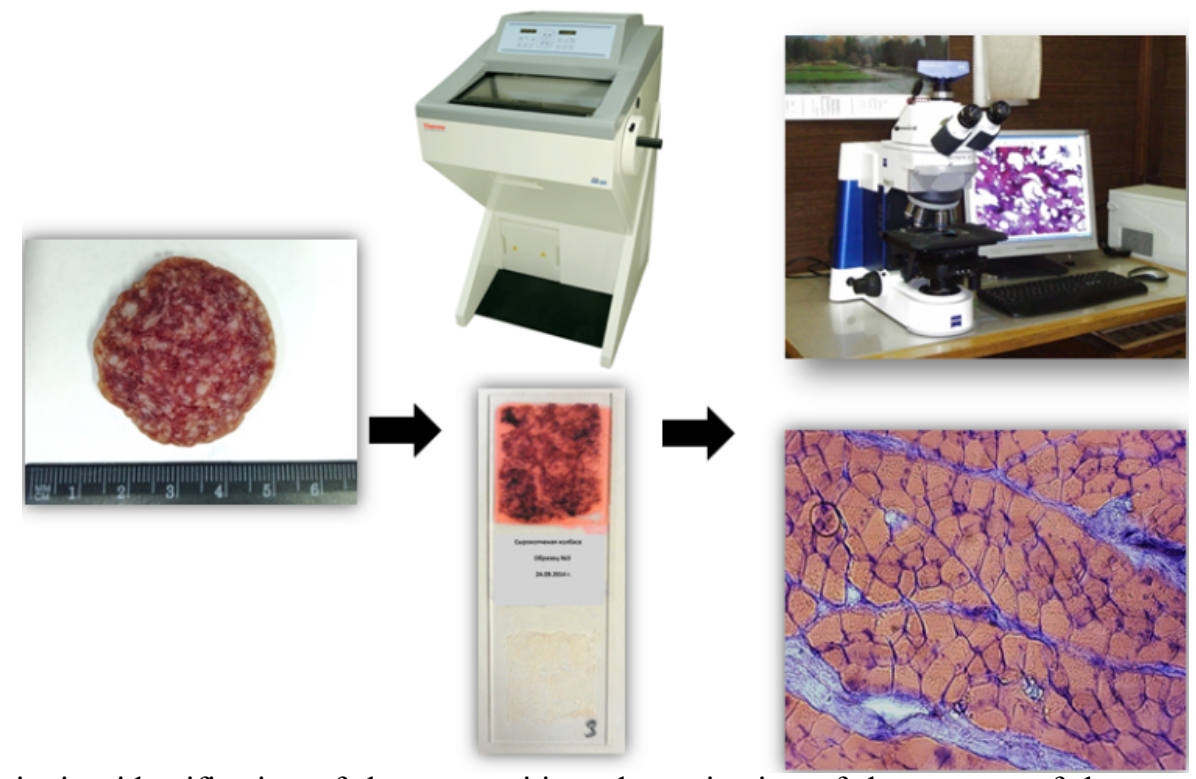

Figure 3 Quantitative identification of the composition: determination of the amount of the component in volume percentages on the Carl Zeiss image analysis system.

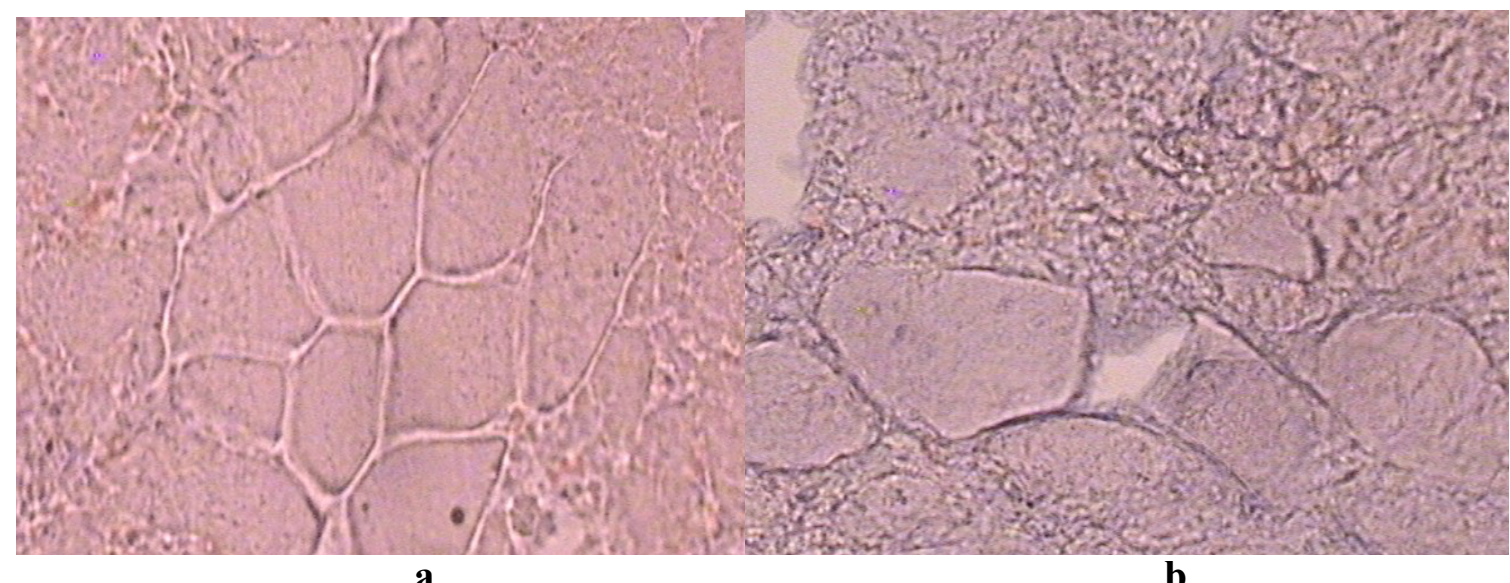

Figure 4 Microstructure of minced meat containing 5\% poultry meat: (a) fragments of muscle tissue (pork) before heat treatment and (b) fragments of muscle tissue (pork) after heat treatment (x340).

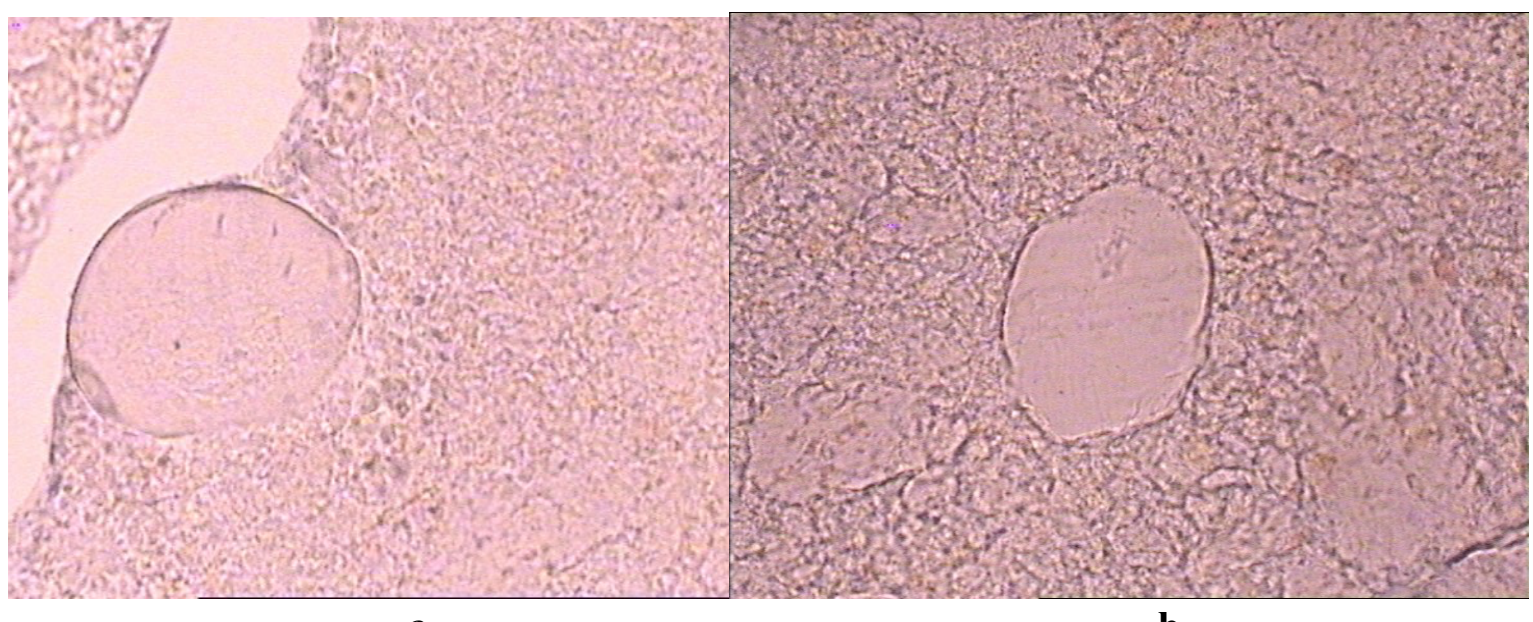

a

b

Figure 5 Microstructure of minced meat containing 5\% of poultry meat: (a) fragments of muscle tissue (poultry) before heat treatment and (b) fragments of muscle tissue (poultry) after heat treatment (x340).

Myoglobin, despite its lower thermal stability compared to sTnI, retains its antigenic properties during heat and enzymatic treatment, so it is an effective alternative biomarker for evaluating various types of raw meat products. We implemented an immunochromatographic test system for the specific detection of porcine myoglobin (Zvereva et al., 2020b). ICA of myoglobin was characterized by a detection limit of $5 \mathrm{ng} \cdot \mathrm{mL}^{-1}$ and a test 
Table 3 Accuracy of the real-time PCR method for identifying finished meat products.

\begin{tabular}{cccc}
\hline Type of raw meat & Processing type & Mean, \% & CV, \% \\
\hline \multirow{2}{*}{ pork } & minced meat mixtures & 103.2 & 7.3 \\
& boiled mix & 98.5 & 5.1 \\
\multirow{2}{*}{ chicken } & minced meat mixtures & 100.3 & 13.1 \\
& boiled mix & 111.8 & 29.5 \\
beef & minced meat mixtures & 85.5 & 20.4 \\
& boiled mix & 110.1 & 13.4 \\
\hline
\end{tabular}

duration of $15 \mathrm{~min}$. The test system was capable of detecting $0.01 \%$ pork additives in ground beef. High reproducibility of ICA results was shown; the RSD of the measured signal intensity was not more than $14 \%$.

Detection of immunoglobulins, which are present in the plasma of all vertebrates and can easily be extracted from muscles, is also an effective approach for identifying sources and assessing the total content of raw meat products. The detection limit of pig immunoglobulin $\mathrm{G}$ in the optimized ICA was $0.5 \mathrm{ng} \cdot \mathrm{mL}^{-1}$, which corresponds to a detection of up to $0.1 \%$ pork. With a different set of immunoreagents, the selective detection of chicken immunoglobulin $\mathrm{Y}$ is provided (Hendrickson et al., 2021). The developed test system allows detecting 0.063\% $0.125 \%$ of chicken meat in samples consisting of one type of meat or a mixture of different types of meat (beef, pork, lamb, and rabbit).

\section{Immunoassay systems}

For the quantitative determination of sTnI, a sandwich ELISA technique was proposed, including sample preparation (protein extraction with $50 \mathrm{mM} \mathrm{K}$-phosphate buffer, $\mathrm{pH} 7.4$, containing $0.1 \mathrm{M} \mathrm{NaCl}$ and $0.5 \mathrm{M} \mathrm{KCl}$ in combination with heat treatment) (Zvereva et al., 2015). The method is characterized by a detection limit for sTnI of $4.8 \mathrm{ng} \cdot \mathrm{mL}^{-1}$ at a concentration range of 8.7 to $52 \mathrm{ng} . \mathrm{mL}^{-1}$. The measurement error in this range does not exceed $6.7 \%$. It has been shown that the developed technique, because of the use of antibodies of a certain specificity, enables the detection of sTnI in samples of mammalian meat (beef, pork, lamb, horse meat) and in samples obtained after technological heat treatment, making it possible to assess the content of mammalian muscle tissue in various types of meat products. At the same time, the developed system does not detect sTnI present in poultry meat (chicken, turkey, duck).

Several complete sets of test systems for the determination of porcine myoglobin in the sandwich ELISA format have been proposed. The method is characterized by a detection limit for myoglobin in the range of 2 to $23 \mathrm{ng} \cdot \mathrm{mL}^{-1}$, depending on the combination of immunoreagents used. A method is proposed for the preparation of samples of raw meat products that makes it possible to extract myoglobin quickly (within $5 \mathrm{~min}$ ) and efficiently.

\section{Assessment of the identification signs of meat products} based on PCR data

Over the years, PCR has established itself as the most promising method for determining the presence of a species in meat, because of its high sensitivity and specificity, as well as its fast processing time and low costs. DNA is naturally stable at high temperatures, at high pressures, and during chemical processing. DNA-based methods rely on the identification of the sequence of certain DNA segments of a particular tissue or animal (Cai et al., 2014; He et al., 2015; Floren et al., 2015). In the category of DNA-based methods, PCR is the most used, simple, effective, sensitive, and specific method that can identify the species of origin presented under various processing conditions (Bottero and Dalmasso, 2011). During this study, experimental characterization of the main types of raw meat products was carried out by the PCR method for all formulations (Table 2 ). The main component of Formulation 1 was pork, with a mass fraction of $60 \%-95 \%$ of muscle tissue. The analysis was carried out for two thermal states of laboratory mixtures: chilled raw meat and meat after heat treatment in a heat chamber. Formulation 2 consisted of pork $(45 \%-$ $72 \% \mathrm{w} / \mathrm{w})$ with beef $(15 \%-24 \% \mathrm{w} / \mathrm{w})$ and chicken $(5 \%-$ $40 \% \mathrm{w} / \mathrm{w}$ ) additives.

The reaction to the positive control (PC) must be as follows: the threshold cycle $\mathrm{Ct}$ (FAM) for the PC must consist of fewer than 20 cycles. Obtaining more than 20 threshold cycles for the PC indicated a deterioration in the quality of the reagents or an improper preparation for the reaction. The reaction to the negative control (NC) must be negative. If a positive reaction to the $\mathrm{NC}$ was obtained, the results of the determination of the samples were considered invalid. The results of the analysis of the test samples were used for analysis only when all the above conditions for the control samples were met. The amplification curves of the formulations under study are shown in Figures $2 \mathrm{a}$ and $2 \mathrm{~b}$. The result of the test samples was considered positive if the difference $\Delta \mathrm{Ct}$ (FAM) of the average values of the threshold cycle of the species-specific reaction of the test sample and the standard sample $(100 \%)$ did not exceed 13 cycles at a signal flare-up level of at least $25 \%$. If there was no reaction or if the difference $\Delta \mathrm{Ct}$ (FAM) of the threshold cycle of the test sample and the standard sample exceeded 13 cycles, the result was considered negative. The accuracy of the data on the type of raw materials for finished meat products is presented in Table 3 . The average values of the accuracy of the PCR method are presented in percentages. During the statistical analysis, threshold values were established for three types of raw meat in the range of 5\% to $30 \%$ deviation for the percentage of raw materials specified at the preparation stage $(p<0.05)$ included in the formulation. An indicator of less than $10 \%$ deviation in accuracy was set for pork, where the percentage in the finished formulation was not less than $57.5 \%(p<0.05)$. For chicken, this indicator was $13.1 \%$ and $29.5 \%$ for raw $(p<0.05)$ and boiled product $(p<0.05)$, respectively. This is because during cooking, the amount of extracted DNA increases. Reducing the error limits is possible only with the use of standard samples that 
have undergone heat treatment. For beef, acceptable error limits were obtained that did not exceed $30 \%$.

Histology

In the initial stage, a semi-quantitative assessment was used according to the following classification of the occurrence of the component:

- in a predominant amount (the component is predominant in the entire volume of the test sample);

- in a sufficient amount (the component in the sample is more than half of the volume);

-in an average amount (the component in the sample is about half of the volume);

- in a moderate amount (the component in the sample is less than half of its volume);

- in a small amount (the component is evenly distributed at least in a small amount in each section of the sample);

- in some cases (the component is detected in single fields of view or sample sections).

Quantification was performed when nonconformity to labeling or product technology was identified (Figure 3). For this, studies were carried out on a computer image analyzer according to the program proposed by the manufacturer, adapted for histological studies. Automatic morphometry, in contrast to manual morphometry, provides data of higher accuracy, which in turn depends on the methods used to prepare the sample for examination and to stain the specimen.

Histological evaluation of samples of one mixture Minced meat, containing poultry and pork, is a finegrained homogeneous mass, including a small number of fragments of muscle, connective tissue, and fat, distributed in the mass of the sample in the form of small droplets. In cross-sections, fragments of muscle tissue of various species differ in the location of the nuclei in the muscle fiber and in the shape of the fiber itself. Muscle fibers of poultry are characterized by a clear round shape and a localization of nuclei throughout the fiber, in contrast to fragments of pig muscle tissue, which have a predominantly polygonal shape and a peripheral arrangement of nuclei (Figure 4 a, b). The indicated morphological differences make it possible to identify the presence of poultry meat in minced meat even in an amount of $5 \%$ of the mass of the minced meat. As studies have shown, heat treatment does not have any effect on the shape of muscle fibers, which makes it possible to identify poultry meat in minced meat after heat treatment (Figure $5 \mathrm{a}, \mathrm{b}$ ).

Histological evaluation of samples of two mixtures

Minced meat, containing poultry, pork, and beef, is a finegrained homogeneous mass, including a small number of fragments of muscle, connective tissue, and fat, distributed in the mass of the sample in the form of small droplets. Fragments of muscle tissue of various species, including beef, differ from poultry meat by the same microstructural characteristics by which pork differs from poultry. These fragments are characterized by a polygonal cross-sectional shape and a peripheral arrangement of nuclei. Muscle fibers of beef differ from pork by a smaller diameter in crosssections and by a pronounced transverse striation in longitudinal sections. In cross-sections, poultry is identified by the shape of the muscle fiber and the arrangement of the nuclei typical of poultry. After heat treatment, the muscle tissue of poultry retains round-shaped muscle fibers, which makes it possible to identify poultry meat in minced meat when the content of poultry meat is from $5 \%$ to $40 \%$ $(p<0.05)$.

\section{Marker identification of research objects}

DNA hybridization and PCR methods, optical fiber chemiluminescence, species-specific protein recognition by immunoassays (ELISA), and HPLC/MS for peptide detection (Khvostov et al., 2019; Montowska and Fornal, 2017) were used to assess the authenticity of meat. Therefore, in the next stage of this study, the method for comparing species-specific peptides for the identification of chicken meat was adapted (Khvostov, Vostrikova and Chernukha, 2020). It has been demonstrated that this approach for the detection of peptides is more effective than PCR and ELISA for determining the origin of products subjected to strong heat treatment or acid-base extraction (Grundy et al., 2016).

In this study, we used the Skyline program (Skyline software, 2021), which is theoretically capable of cleaving proteins and making a list of SRMs for each peptide (Table 4). Protein analysis was performed using biomodelling. The peptides presented in a recent review (Stachniuk et al., 2019) were selected for the comparison of potential biomarkers. These included more than 20 heat-resistant chicken markers from 2010 to 2019. This large number of markers is due to chicken being the most consumed meat in the world (Escriba-Perez et al., 2017). Chicken meat is often used as a substitute for more expensive types of meat. Table 4 lists proteins such as creatine kinase $M$, myosin, $\beta$ enolase, M-proteins, and pyruvate kinase. They are a source of thermostable peptides.

For myosin chains, nine heat-resistant peptides were analyzed. The myosin family is the most representative peptide family in white meat because of its role in muscle contraction (Pan et al., 2018). Two markers can be distinguished in Figure 4. The first marker is the DQGTFEDFVEGLR peptide, which showed a signal value of $(10-30) * 10^{3} \mathrm{cps}$. These findings agree with studies by Sentandreu et al. (2010) and Wang et al. (2018), where only this peptide was found. The second marker is the VAGAALPCAPAVK peptide (Montowska and Fornal, 2017; Montowska and Fornal, 2019), for which the transitions are shown in Figure 7. Its signal value was (10$110) * 10^{3} \mathrm{cps}$, which was the highest value among all analyzed peptides. This new finding may shift the focus to VAGAALPCAPAVK.

The peptides SAMLQLAVTEIEK (Montowska and Fornal, 2017), DLFDPVIQDR (Li et al., 2018), LSVEALNSLEGEFK, LAMQEFMVLPVGAASFHDAMR (Claydon et al., 2015) showed a signal value of $(10-90) * 10^{3} \mathrm{cps}$. However, the spread $(p<0.05)$ was more than $50 \%$ (Figure 6$)$. This can affect results during enzymatic hydrolysis and sample preparation. The analysis results will not be able to pass the convergence threshold of $25 \%$.

Development of a two-level control system for the composition of meat products

The development of improved methodologies based on mass spectrometry, ELISA, and ICA with the ability to quantify specific proteins in complex biological matrices and to determine the level of protein expression is a promising direction. 


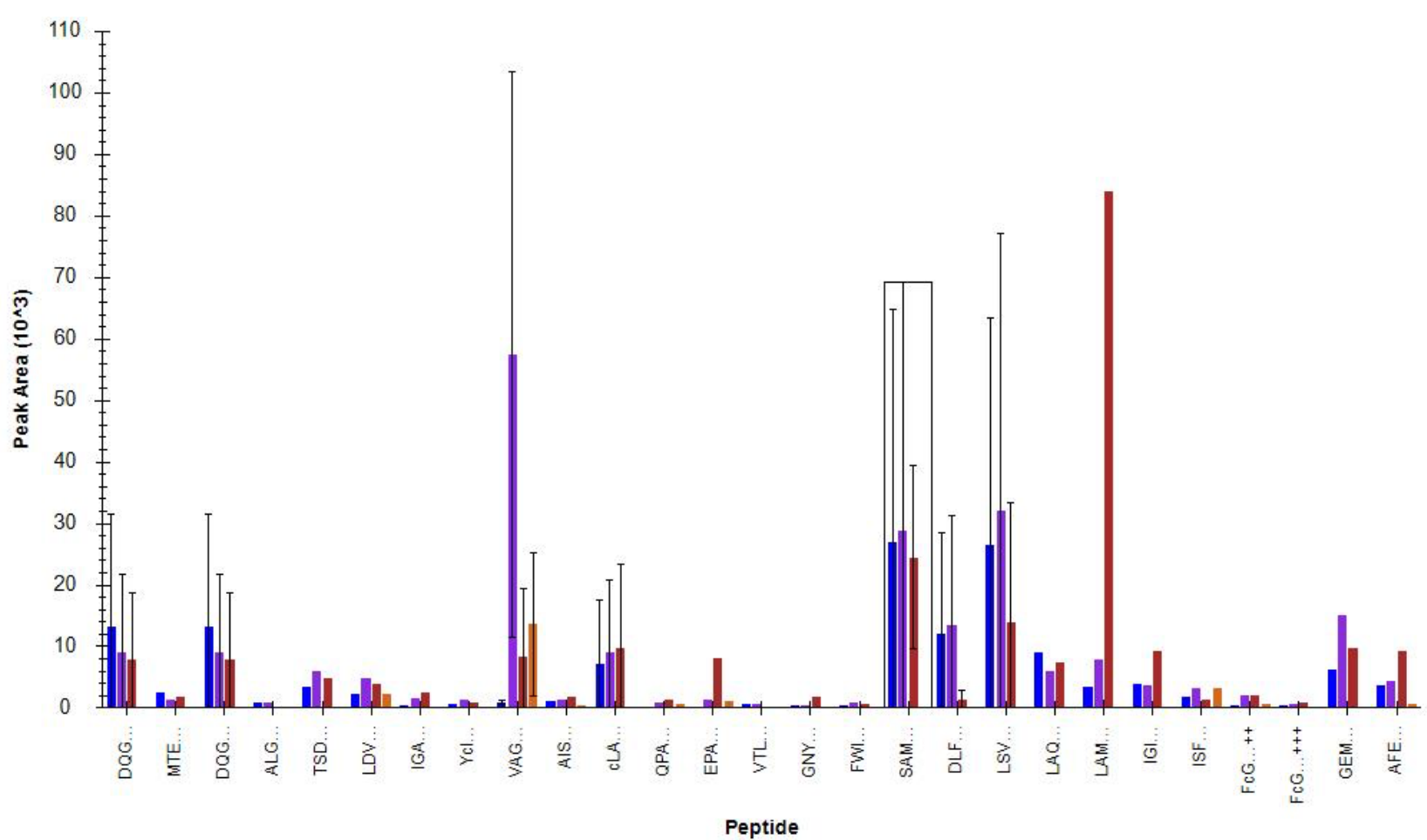

Figure 6 Comparison of the areas of chicken marker peptides for all MRMs of the studied samples.

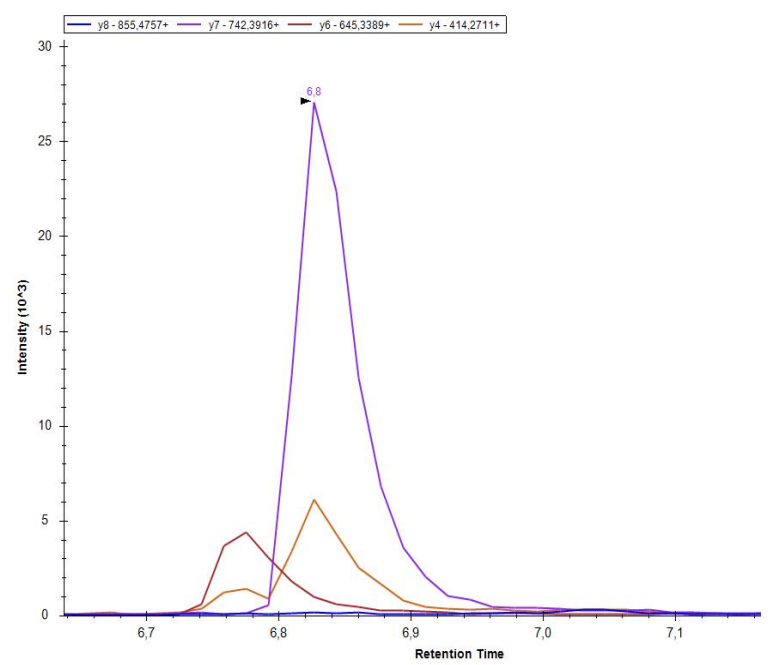

Figure 7 Retention time, transitions, and daughter ion mass spectrum for the species-specific peptide VAGAALPCAPAVK.

In the past decade, there has been a rapid introduction of ELISA into the practice of food laboratories because of technical improvements in this method and the need for fast, sensitive, specific, and simple methods. The determination of species-specific proteins by ELISA is carried out using various test systems: systems for species-specific serum albumin and troponin I and systems for thermostable glycoproteins. Such test systems are designed for ruminants, pork, horse meat, small cattle, and poultry (chicken, turkey) (Thienes et al., 2019). At the same time, there is a need to determine the composition of structureless meat products that have been exposed to heat and that may contain additional animal ingredients. Systems based on a single methodology are, as a rule, still not able to determine the content of these products. This paper presents a model for the development of a two-level control system for determining the origin of raw materials in meat products.
It seemed interesting to create an assessment system for controlling the composition of meat products, aimed at identifying cases of violation of established recipes using a two-level system of screening and arbitration. Table 5 presents a comparative assessment of the methodologies used, assessed to identify the muscle proteins in raw meat and products made from it. The table also includes twodimensional electrophoresis. In the comparative study of this article, prototypes of this methodology were not considered, but we studied it in detail. Some aspects of this methodology were used in practice, and its performance was validated and confirmed by mass spectrometry (Vostrikova et al., 2017)

Thus, a review of existing methodological approaches and their experimental confirmation revealed the absence of one specific method that would solve such an urgent problem as the quantitative determination of undeclared components in 
meat products. According to the prospects for inclusion in the system of multilevel control of the composition of meat products, ICA and/or ELISA (low-cost methods, with a high level of reliability) is recommended as a screening method, and LC-MS as an arbitration (confirming) identification method $(p<0.05)$ (Figure 8). When analyzing the complementarity of the considered methods, it is worth using two or three methods together:

- ELISA/ICA: within the framework of production control laboratories, in the context of rapid decision-making;
- ELISA/MS: within the framework of confirmatory (arbitration) control, as the most highly reliable method;

- ICA/2D electrophoresis biomarker identification / MS: within the framework of confirmatory (controversial) control, as the most demonstrative confirmation.

When creating a multilevel control system for the composition of meat products, it is proposed to use the principle of a decision tree, as shown in Figure 5.

Table 4 Identification characteristics of heat-stable chicken peptide markers for the LC-MS/MS methods.

\begin{tabular}{|c|c|c|c|c|}
\hline Protein & Marker peptide sequence & $\begin{array}{c}\text { Parent ion }(m / z), \text { product } \\
\text { ions }(m / z)\end{array}$ & $\begin{array}{c}\text { Collision } \\
\text { energy } \\
\text { (V) }\end{array}$ & References* \\
\hline \multirow[t]{2}{*}{$\begin{array}{l}\text { Myosin light } \\
\text { chain } 1\end{array}$} & MTEEEVEELMK & $\begin{aligned} & 684.3 \rightarrow 1006.5,877.4, \\
& 748.4\end{aligned}$ & 22.2 & Wang et al. (2018) \\
\hline & DQGTFEDFVEGLR & $\begin{aligned} & 756.9 \rightarrow 1111.5,964.5 \\
& 835.4\end{aligned}$ & 24.5 & $\begin{array}{l}\text { Sentandreu et al. } \\
\text { (2010), Wang } \\
\text { et al. (2018) }\end{array}$ \\
\hline \multirow[t]{3}{*}{$\begin{array}{l}\text { Myosin light } \\
\text { chain } 3\end{array}$} & ALGQNPTNAEINK & $\begin{aligned} & 685.4 \rightarrow 886.5,789.4 \\
& 688.4\end{aligned}$ & 22.2 & $\begin{array}{l}\text { Sentandreu } \\
\text { et al. (2010) }\end{array}$ \\
\hline & TSDVDSVFFIR & $\begin{aligned} & 643.3 \rightarrow 1097.6,883.5 \\
& 582.3\end{aligned}$ & 20.9 & $\begin{array}{l}\text { Montowska and } \\
\text { Fornal }(2017,2019)\end{array}$ \\
\hline & LDVPISGEPAPTVTWK & $\begin{array}{c}855.5 \rightarrow 1085.6,1028.5 \\
899.5,731.4\end{array}$ & 27.5 & $\begin{array}{c}\text { Montowska and } \\
\text { Fornal }(2017,2019)\end{array}$ \\
\hline \multirow[t]{3}{*}{$\begin{array}{l}\text { Myosin-binding } \\
\text { protein } C\end{array}$} & IGAGGVDGYLVEWCR & $\begin{array}{c}826.4 \rightarrow 1353.6,1197.5, \\
650.3\end{array}$ & 26.6 & $\begin{array}{c}\text { Montowska and } \\
\text { Fornal (2017), } \\
\text { Fornal and } \\
\text { Montowska (2019) }\end{array}$ \\
\hline & YCITVTNPVGEDSATLHVR & $\begin{aligned} & 1066.5 \rightarrow 1280.7,1183.6 \\
& 783.5\end{aligned}$ & 34.1 & $\begin{array}{l}\text { Montowska and } \\
\text { Fornal (2017), } \\
\text { Fornal and } \\
\text { Montowska (2019) }\end{array}$ \\
\hline & VAGAALPCAPAVK & $\begin{array}{c}612.8 \rightarrow 855.5,742.4 \\
645.3,414.3\end{array}$ & 20.0 & $\begin{array}{c}\text { Montowska and } \\
\text { Fornal }(2017,2019)\end{array}$ \\
\hline $\begin{array}{l}\text { Myosin-binding } \\
\text { protein } \mathrm{H}\end{array}$ & AISASGTSDPATLEQPVLIR & $\begin{array}{c}1013.5 \rightarrow 1236.7,1139.7 \\
1068.6,597.4\end{array}$ & 32.4 & $\begin{array}{l}\text { Montowska and } \\
\text { Fornal (2017) }\end{array}$ \\
\hline \multirow[t]{2}{*}{ Pyruvate kinase } & CLAAALIVMTESGR & $\begin{aligned} & 746.4 \rightarrow 1005.5,892.5 \\
& 779.4\end{aligned}$ & 24.1 & Wang et al. (2018) \\
\hline & QPAHDAWAEDVDLR & $\begin{array}{c}811.9 \rightarrow 1494.7,1074.5 \\
1003.5,817.4\end{array}$ & 26.2 & Li et al. (2018) \\
\hline $\begin{array}{l}\text { Pyruvate kinase } \\
\text { (P00548.2) }\end{array}$ & EPADAMAAGAVEASFK & $\begin{array}{c}782.9 \rightarrow 1152.6,950.5 \\
879.5,950.5,808.4\end{array}$ & 25.3 & $\begin{array}{c}\text { Montowska and } \\
\text { Fornal (2017, } \\
\text { 2019), } \\
\text { Montowska and } \\
\text { Fornal (2019) }\end{array}$ \\
\hline \multirow[t]{2}{*}{ M-protein } & GNYTFEIFSDK & $\begin{aligned} & 660.8 \rightarrow 986.5,885.4 \\
& 738.4\end{aligned}$ & 21.5 & Wang et al. (2018) \\
\hline & FWIQAESLSPNSTYR & $\begin{aligned} 899.9 & \rightarrow 1153.5,1024.5 \\
& 937.5,737.4\end{aligned}$ & 28.9 & \\
\hline Troponin I & SAMLQLAVTEIEK & $\begin{aligned} & 716.9 \rightarrow 902.5,789.4 \\
& 718.4\end{aligned}$ & 23.2 & $\begin{array}{l}\text { Montowska and } \\
\text { Fornal (2017) }\end{array}$ \\
\hline \multirow[t]{2}{*}{$\begin{array}{l}\text { Creatine kinase } \\
\text { M-type }\end{array}$} & DLFDPVIQDR & $\begin{array}{c}609.3 \rightarrow \\
6442.5,727.4 \\
630.4\end{array}$ & 19.9 & Li et al. (2018) \\
\hline & LSVEALNSLEGEFK & $\begin{aligned} & 768.4 \rightarrow 1036.5,923.4 \\
& 809.4\end{aligned}$ & 24.8 & $\begin{array}{c}\text { Claydon } \\
\text { et al. (2015) }\end{array}$ \\
\hline \multirow[t]{2}{*}{$\beta$-enolase } & LAQSHGWGVMVSHR & $\begin{aligned} 782.9 \rightarrow & 1028.5,971.5 \\
785.4 & \end{aligned}$ & 25.3 & Li et al. (2018) \\
\hline & LAMQEFMVLPVGAASFHDAMR & $\begin{aligned} 1161.0 \rightarrow & 1371.6,1258.6 \\
& 1161.5\end{aligned}$ & 37.0 & $\begin{array}{l}\text { Claydon } \\
\text { et al. (2015) }\end{array}$ \\
\hline
\end{tabular}

Note: * Only the peptide sequence provided in the review article by Stachniuk et al. (2019). The MRM transitions and collision energy metrics were selected anew. 


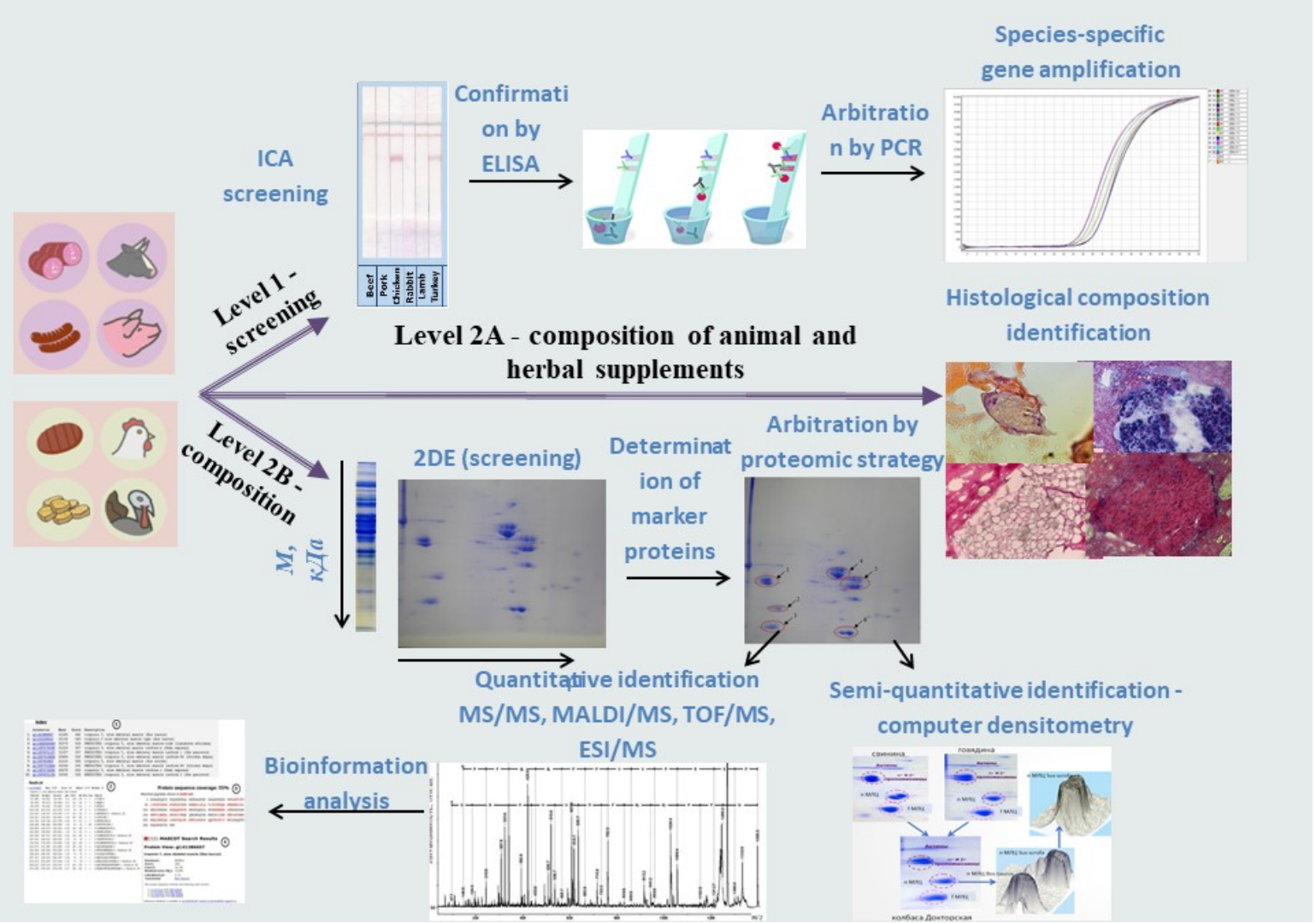

Figure $8 \mathrm{~A}$ two-level control system for the composition of meat products.

Table 5 Comparative assessment of screening and arbitration control methods.

\begin{tabular}{|c|c|c|c|c|c|}
\hline Method & $\begin{array}{c}\text { Time per } \\
\text { sample / } \\
\text { confidence } \\
\text { level }\end{array}$ & $\begin{array}{l}\text { Cost level for } \\
\text { reagents (kit) } \\
*\end{array}$ & Cost level** & $\begin{array}{c}\text { Inclusion in } \\
\text { the system } \\
\text { of } \\
\text { multilevel } \\
\text { control } \\
\end{array}$ & Reference \\
\hline Histology & $48 \mathrm{~h} / 80 \%$ & low cost & costly & no & $\begin{array}{c}\text { Khvylya, Pchelkina } \\
\text { and Burlakova } \\
(\mathbf{2 0 1 2})\end{array}$ \\
\hline Real-time PCR & $5 \mathrm{~h} / 99 \%$ & medium cost & costly & yes & $\begin{array}{l}\text { Cai et al. (2014), He } \\
\text { et al. (2015), Floren } \\
\text { et al. (2015) }\end{array}$ \\
\hline 2-DE (screening) & $24 \mathrm{~h} / 80 \%$ & costly & medium cost & no & $\begin{array}{c}\text { Akhremko and } \\
\text { Vasilevskaya }(2020, \\
\text { 2021) }\end{array}$ \\
\hline $\begin{array}{l}\text { 2-DE (biomarker } \\
\text { identification) }\end{array}$ & $48 \mathrm{~h} / 95 \%$ & costly & costly & yes & $\begin{array}{c}\text { Akhremko and } \\
\text { Vasilevskaya }(2020, \\
\text { 2021) }\end{array}$ \\
\hline $\begin{array}{l}\text { 2-DE (densitometric } \\
\text { quantity confirmation) }\end{array}$ & $48 \mathrm{~h} / 85 \%$ & costly & costly & yes & $\begin{array}{c}\text { Akhremko and } \\
\text { Vasilevskaya }(2020, \\
\text { 2021) }\end{array}$ \\
\hline LC/MS-MS & $5 \mathrm{~h} / 99 \%$ & costly & costly & yes & $\begin{array}{c}\text { Kulikovskii et al. } \\
\text { (2019) }\end{array}$ \\
\hline ELISA & $3.5 \mathrm{~h} / 95 \%$ & low cost & medium cost & yes & $\begin{array}{c}\text { Zvereva et al. (2015) } \\
\text { Zvereva et al. }\end{array}$ \\
\hline $\begin{array}{l}\text { Lateral flow } \\
\text { immunosensor }\end{array}$ & $0.3 \mathrm{~h} / 45 \%$ & low cost & low cost & yes & $\begin{array}{l}(2020 \mathrm{a}, 2020 \mathrm{~b}) \\
\text { Hendrickson et al. } \\
(2021)\end{array}$ \\
\hline
\end{tabular}

Note: * Level of costs for reagents (kit): low cost (less than $500 €)$, medium cost (500-1000 €), costly (more than $1000 €)$; ** The level of costs for auxiliary equipment and measuring instruments: low cost (less than $1000 €)$, medium cost (1000$10000 €$ ), costly (more than $10000 €$ ). 
The primary task for the execution and final selection of methods that will be included in the multilevel control system is the development of standards for the products under study and a description of the result of the methods used (see Table 5). Similar approaches are applicable to all meat products that contain proteins of muscle origin. Thus, the proposed methodology can have a wide range of applications. Applied proteomics and immunodetection aimed at finding biomarkers, the composition of products of plant and animal origin, and the identification signs of the authenticity of products require a completely different approach from that of classical protein analysis, which requires a more detailed study or complete mapping of the sequence of a known protein.

\section{CONCLUSION}

Based on the economic feasibility (costs, research time, and reliability) of the methodology, ELISA and ICA were proposed as screening methods. The advantage of troponins, as thermostable biomarkers of muscle tissue, has been shown in the identification of meat. This made it possible to distinguish between the muscle tissues of mammals (beef, pork, lamb, horse) and poultry (chicken, turkey, duck). With ELISA, the evaluation time could be reduced to $30-40 \mathrm{~min}$.

Using a video-digital recording of the intensity of staining of the analytical zone of the test strip in the ICA, this analysis can be transformed from a qualitative into quantitative analysis, using portable optical detectors, such as video cameras of serial communication devices, as well as standard office scanners. The standard deviation of the measurements of the biomarker concentration did not exceed $10 \%$.

Highly sensitive methodologies, such as identifying the amount of muscle tissue by a marker peptide, were also evaluated. Monitoring of multiple reactions of specific peptides by mass spectrometry (MPM-MS) was accepted as an arbitration method and proposed for confirmatory analyses. Proteins from meat were extracted using trypsin, the mixture of peptides was analyzed by high-performance liquid chromatography using QQQ-MS, and candidate proteins were characterized using Skyline software. The choice of species-specific proteins and their peptides (more than six amino acids) was based on the high content in muscles, in terms of the signal-to-noise ratio, in the absence of missing fragments. Myoglobin and lactate dehydrogenase were chosen as biomarker proteins. A simplified regulation scheme is proposed for action: screening and arbitration control. It is recommended to introduce such use of the various methodologies into the sphere of state regulation at the level of control bodies.

\section{REFERENCES}

Akhremko, A., Fedulova, L. 2021. Comparative study of weaning pigs' muscle proteins using two-dimensional electrophoresis. Potravinarstvo Slovak Journal of Food Sciences, vol. 15, no. 1, p. 52-57. https://doi.org/10.5219/1449 Akhremko, A., Vasilevskaya, E., Fedulova, L. 2020. Adaptation of two-dimensional electrophoresis for muscle tissue analysis. Potravinarstvo Slovak Journal of Food Sciences, vol. 14, no. 1, p. 595-601. https://doi.org/10.5219/1380
Ali, M., Kashif, M., Uddin, K., Hashim, U., Mustafa, S., Man, C. 2012. Species authentication methods in foods and feeds: the present, past, and future of halal forensics. Food Analytical Methods, vol. 5, no. 5, p. 935-955. https://doi.org/10.1007/s12161-011-9357-3

Bottero, M., Dalmasso, A. 2011. Animal species identification in food products: Evolution of biomolecular methods. The Veterinary Journal, vol. 190, no. 1, p. 34-38. https://doi.org/10.1016/j.tvj1.2010.09.024

Cai, Y., Li, X., Lv, R., Yang, J., Li, J., He, Y., Pan, L. 2014. Quantitative analysis of pork and chicken products by droplet digital PCR. BioMed research international, vol. 2014, 6 p. https://doi.org/10.1155/2014/810209

Calvo, J., Zaragoza, P., Osta, R. 2001. A quick and more sensitive method to identify pork in processed and unprocessed food by PCR amplification of a new specific DNA fragment. Journal of animal science, vol. 79, no. 8, p. 2108-2112. https://doi.org/10.2527/2001.7982108x

Chernukha, I. M., Vostrikova, N. L., Khvostov, D. V., Zvereva, E. A., Taranova, N. A., Zherdev, A. V. 2019. Methods of identification of muscle tissue in meat products. prerequisites for creating a multi-level control system. Theory and practice of meat processing, vol. 4, no. 3, p. 32-40. https://doi.org/10.21323/2414-438X-2019-4-3-32-40

Claydon, A., Grundy, H., Charlton, A., Romero, M. 2015. Identification of novel peptides for horse meat speciation in highly processed foodstuffs. Food Addit Contam-Part A Chem Anal Control Expo Risk Asses, vol. 32, no. 10, p. 17181729. https://doi.org/10.1080/19440049.2015.1075256

Escriba-Perez, C., Baviera-Puig, A., Buitrago-Vera, J., Montero-Vicente, L. 2017. Consumer profile analysis for different types of meat in Spain. Meat science, vol. 129, p. 120126. https://doi.org/10.1016/j.meatsci.2017.02.015

Federal Ministry of Food and Agriculture. 2021. Available at: https://www.bmel.de.

Floren, C., Wiedemann, I., Brenig, B., Schütz, E., Beck, J. 2015. Species identification and quantification in meat and meat products using droplet digital PCR (ddPCR). Food chemistry, vol. 173, p. 1054-1058. https://doi.org/10.1016/j.foodchem.2014.10.138

Fornal, E., Montowska, M. 2019. Species-specific peptidebased liquid chromatography-mass spectrometry monitoring of three poultry species in processed meat products. Food Chem., vol. 283, p. 489-498. https://doi.org/10.1016/j.foodchem.2019.01.074

Grundy, H., Reece, P., Buckley, M., Solazzo, C., Dowle, A., Ashford, D., Charlton, A., Wadsley, M., Collins, M. 2016. A mass spectrometry method for the determination of the species of origin of gelatine in foods and pharmaceutical products. Food Chem., vol. 190, p. 276-284. https://doi.org/10.1016/j.foodchem.2015.05.054

He, H., Hong, X., Feng, Y., Wang, Y., Ying, J., Liu, Q., Qian, Y., Zhou, X., Wang, D. 2015. Application of quadruple multiplex PCR detection for beef, duck, mutton and pork in mixed meat. Journal of Food and Nutrition Research, vol. 3, p. 392-398. https://doi.org/10.12691/jfnr-3-6-6

Hendrickson, O. D., Zvereva, E. A., Vostrikova, N. L., Chernukha, I. M., Dzantiev, B. B., Zherdev, A. V. 2021. Lateral flow immunoassay for sensitive detection of undeclared chicken meat in meat products. Food Chem., vol. 15, p. 344. https://doi.org/10.1016/j.foodchem.2020.128598

Khvostov, D. V., Vostrikova, N. L. Zherdev, A. V., Zvereva, E. A., Kurzova, A. A. 2019. Identifikatsiya i kolichestvennoye opredeleniye myshechnoy tkani na osnove kontrolya prototipicheskikh peptidov $\mathrm{s}$ ispol'zovaniyem metoda monitoringa zadannykh reaktsiy (Quantitative identification of 
muscular tissue by the means of protototic peptides using the multiple reaction monitoring method). Analitika i kontrol', vol. 23, no. 4, p. 580-586. http://doi.org/10.15826/analitika.2019.23.4.012 (In Russian)

Khvostov, D., Vostrikova, N., Chernukha, I. 2020. Comparison of heat-stable peptides using a multiple-reaction monitoring method to identify beef muscle tissue. Potravinarstvo Slovak Journal of Food Sciences, vol. 14, no. 1, p. 149-155. https://doi.org/10.5219/1317

Khvylya, S., Pchelkina, V., Burlakova, S. 2012. Primeneniye gistologicheskogo analiza pri issledovanii myasnogo syr'ya $\mathrm{i}$ gotovykh produktov (The use of histological analysis in the study of raw meat and finished products). Tekhnika $i$ tekhnologiya pishchevykh proizvodstv, vol. 3, p 132-138. (In Russian)

Kulikovskii, A. V., Vostrikova, N. L., Chernukha, I. M., Khvostov, D. V. 2019. Quantitative identification of muscle tissue by means of biomarker peptides by using method of multiple reaction monitoring. Oriental J. of Chemistry, vol. 35, no. 4, p. 1327-1331. http://doi.org/10.13005/ojc/350411.

Kurbakov, K. A., Konorov, E. A., Minaev, M. Y., Kuznetsova, O. A., 2019. Multiplex real-time PCR with HRM for detection of Lactobacillus sakei and Lactobacillus curvatus in food samples. Food technology and biotechnology, vol. 57, no. 1, p. 97-104. https://doi.org/10.17113/ftb.57.01.19.5983

Li, Y., Zhang, Y., Li, H., Zhao, W., Guo, W., Wang, S. 2018. Simultaneous determination of heat stable peptides for eight animal and plant species in meat products using UPLC-MS/MS method. Food Chem, vol. 245, p. 125-131. https://doi.org/10.1016/j.foodchem.2017.09.066

Montowska, M., Fornal, E. 2017. Label-free quantification of meat proteins for evaluation of species composition of processed meat products. Food Chem., vol. 237, no. 15, p. 1092-1100. https://doi.org/10.1016/i.foodchem.2017.06.059

Montowska, M., Fornal, E. 2019. Absolute quantification of targeted meat and allergenic protein additive peptide markers in meat products. Food Chem, vol. 274, p. 857-864. https://doi.org/10.1016/j.foodchem.2018.08.131

Moore, J., Spink, J., Lipp, M. 2012. Development and application of a database of food ingredient fraud and economically motivated adulteration from 1980 to 2010 . Journal of food science, vol. 77, no. 4, p. 118-126. https://doi.org/10.1111/i.1750-3841.2012.02657.x

Pan, X.-D., Chen, J., Chen, Q., Huang, B.-F., Han, J.-L. 2018. Authentication of pork in meat mixtures using PRM mass spectrometry of myosin peptides. RSC $A d v$., vol. 8, no. 20, p. 11157-11162. https://doi.org/10.1039/C8RA00926K

Sentandreu, M., Fraser, P., Halket, J., Patel, R., Bramley, P. 2010. A proteomic based approach for detection of chicken in meat mixes. Journal of Proteome Research, vol. 9, no. 7, p. 3374-3383. https://doi.org/10.1021/pr9008942

Skyline software. 2021. Available at: https://skyline.ms/project/home/software/Skyline/begin.view.

Stachniuk, A., Sumara, A., Montowska, M., Fornal, E. 2019. Liquid chromatography-mass spectrometry bottom-up proteomic methods in animal species analysis of processed meat for food authentication and the detection of adulterations. Mass Spectrometry Reviews, vol. 00, p. 1-28. https://doi.org/10.1002/mas.21605

Thienes, C., Masiri, J., Benoit, L. A., Barrios-Lopez, B., Samuel, S., Meshgi, M., Cox, D., Dobritsa, A., Nadala, C., Samadpour, M. 2019. Quantitative detection of chicken and turkey contamination in cooked meat products by ELISA. Journal of AOAC International, vol. 102, no. 2, p. 557-563. https://doi.org/10.5740/jaoacint.18-0136
Vostrikova, N., Kulikovskiy, A., Chernukha, I., Kovalev, L., Savchuk, S. 2017. Opredeleniye belkov myshechnoy tkani metodami 2D elektroforeza i vremyaproletnoy massspektrometrii (Determination of muscle tissue proteins by 2D electrophoresis and time-of-flight mass spectrometry.). Zhurnal analiticheskoy khimii, vol. 72, p. 932-943. https://doi.org/10.7868/S0044450217100103 (In Russian)

Wang, G.-J., Zhou, G.-Y., Ren, H.-W., Xu, Y., Yang, Y., Guo, L.-H., Liu, N. 2018. Peptide biomarkers identified by LC-MS in processed meats of five animal species. $J$ Food Comp Anal, vol. 73, p. 47-54. https://doi.org/10.1016/j.jfca.2018.07.004

Zvereva, E. A., Byzova, N. A., Hendrickson, O. D., Popravko, D. S., Belichenko, K. A., Dzantiev, B. B., Zherdev, A. V. 2020b. Immunochromatographic detection of myoglobin as a specific biomarker of porcine muscle tissues in meat products. Applied Sciences, vol. 10, no. 21, p. 7437. https://doi.org/10.3390/app10217437

Zvereva, E. A., Kovalev, L. I., Ivanov, A. V., Kovaleva, M. A., Zherdev, A. V., Shishkin, S. S., Lisitsyn, A. B., Chernukha, I. M., Dzantiev, B. B. 2015. Enzyme immunoassay and proteomic characterization of troponin $\mathrm{I}$ as a marker of mammalian muscle compounds in raw meat and some meat products. Meat Science, vol. 105, p. 46-52. https://doi.org/10.1016/j.meatsci.2015.03.001

Zvereva, E. A., Popravko, D. S., Hendrickson, O. D., Vostrikova, N. L., Chernukha, I. M., Dzantiev, B. B., Zherdev, A. V. 2020a. Lateral flow immunoassay to detect the addition of beef, pork, lamb, and horse muscles in raw meat mixtures and finished meat products. Foods, vol. 9, no. 11, p. 1662. https://doi.org/10.3390/foods9111662

\section{Funds:}

This work was supported by the Russian Foundation for Basic Research, project No. 19-316-90053 (Selection of marker peptides by $\mathrm{LC}-\mathrm{MS} / \mathrm{MS}$ ).

This work was supported by the Russian Science Foundation, project No. 19-16-00108 (all other studies);

\section{Conflict of Interest:}

The authors declare no conflict of interest.

\section{Ethical Statement:}

This article does not contain any studies that would require an ethical statement.

\section{Contact Address:}

*Natalya Vostrikova, V. M. Gorbatov Federal Research Center for Food Systems of RAS, Laboratory Center for food and feed testing, Talalikhina st., 26, 109316, Moscow, Russia, Tel.: +74956767981,

E-mail:n.vostrikova@fncps.ru

ORCID: https://orcid.org/0000-0002-9395-705X

Daniil Khvostov, V. M. Gorbatov Federal Research Center for Food Systems of RAS, Laboratory of molecular biology and bioinformatics, Talalikhina st., 26, 109316, Moscow, Russia, Tel.: +74956767981,

E-mail:d.hvostov@,fncps.ru

ORCID: https://orcid.org/0000-0002-3445-4559

Anatoly Zherdev, Research Center of Biotechnology RAS, Laboratory of immunobiochemistry, Leninsky prospect, 33, 119071, Moscow, Russia, Tel.: $+74959542804$

E-mail: zherdev@,inbi.ras.ru 
ORCID: https://orcid.org/0000-0003-3008-2839

Mikhail Minaev, V.M. Gorbatov Federal Research Center for Food Systems of RAS, Laboratory of molecular biology and bioinformatics, Talalikhina st., 26, 109316, Moscow, Russia, Tel.: +74956767981,

E-mail: mminaev@,inbox.ru

ORCID: https://orcid.org/ 0000-0002-0038-9744
Elena Zvereva, Research Center of Biotechnology RAS, Laboratory of immunobiochemistry, Leninsky prospect, 33, 119071, Moscow, Russia, Tel.: +74959542804, E-mail: zverevaea@yandex.ru ORCID: http://orcid.org/ 0000-0002-8709-2061

Corresponding author: * 